\title{
(En)canto científico: temas de ciência em letras da música popular brasileira
}

\author{
Scientific enchantment: science topics in the lyrics of popular \\ Brazilian music
}

Ildeu de Castro Moreira

Instituto de Física

Universidade Federal do

Rio de Janeiro - UFRJ

Praia do Flamengo 200, 8o andar,

Flamengo

22210-030 Rio de Janeiro - RJ -

Brasil

icmoreira@uol.com.br

icmoreira@mct.gov.br

\section{Luisa Massarani}

Centro de Estudos, Museu da Vida, Casa de Oswaldo Cruz Fundação Oswaldo Cruz - Fiocruz Av. Brasil 4365, Manguinhos 21040-360 Rio de Janeiro - RJ Brasil

cestudos@coc.fiocruz.br
MOREIRA, I. de C.; MASSARANI, L.: (En)canto científico: temas de ciência em letras da música popular brasileira. História, Ciências, Saúde - Manguinhos, v. 13 (suplemento), p. 291-307, outubro 2006.

As relações entre ciência e música são muito profundas e têm suas raízes no próprio surgimento da ciência moderna. A música tem uma base física importante: são os sons afinados pela cultura que a constituem. Por outro lado, ela foi utilizada muitas vezes como metáfora e como inspiração para interpretar o mundo físico, em particular nos modelos cosmológicos. Este artigo explora, de forma preliminar, como surgem e se expressam temas e visões sobre a ciência, a tecnologia e seus impactos na vida moderna nas letras de canções da música popular brasileira. O objetivo primordial do trabalho - que constitui uma análise qualitativa não-exaustiva - é proceder a um mapeamento inicial de como temas de ciência, atividade social imersa em determinado contexto cultural, podem surgir na manifestação das artes populares, neste caso a música brasileira.

PALAVRAS-CHAVE: ciência e música; letras musicais; divulgação científica.

MOREIRA, I. de C.; MASSARANI, L. Scientific enchantment: science topics in the lyrics of popular Brazilian music. História, Ciências, Saúde-Manguinhos, v. 13 (supplement), p. 291-307, October 2006.

The links between science and music are deep and their roots are directly associated to the emergence of modern science. Music has an important background in physics: it is made up of sounds tuned by culture. Concomitantly, it has often served as a metaphor and as an inspiration in how we interpret our physical world, especially in cosmological models. This paper offers an initial exploration of how topics and outlooks on science and technology have emerged and had an impact on the lyrics of popular Brazilian music in modern life. This non-comprehensive qualitative analysis aims at to be a starting point for a preliminary sketch of how topics involving science-which is a social activity immersed in a specific cultural context-can make their way into popular art forms, in this case, Brazilian music.

KEYWORDS: science and music; lyrics; science communication. 


\author{
Sei que a arte éirmã da ciência \\ Ambas filhas de um Deus fugaz \\ Gilberto Gil, “Quanta”, 1995
}

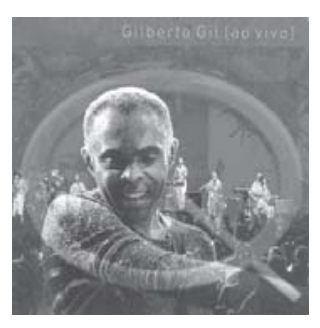

Reprodução de capa do cd Quantas, cedida pela Warner Music.
A música é uma das artes mais ligadas à matemática e à física. Até os albores do século XVI, ela era considerada um ramo da matemática. No período medieval constituía uma de suas disciplinas, integrando o quadrivium: aritmética, geometria, astronomia e música. Tomava-se, então, como música os seus aspectos teóricos sem ligação direta com sua execução prática. Ela é uma arte escorada em medidas precisas, o que garante nova aproximação com a ciência, e tem uma base física importante: são os sons afinados pela cultura que a constituem.Por outro lado, ela foi usada muitas vezes como metáfora e como inspiração para interpretar o mundo, em particular nos modelos cosmológicos, ou em tentativas descritivas da estrutura da sociedade humana.

Se as descobertas científicas e os avanços técnicos estimularam mudanças e transformações na música em muitos aspectos, o oposto também se verificou. Em diversos períodos da história questões emanadas da música estimularam a investigação científica. Especulações sobre a natureza musical do universo remontam a milênios atrás. A harmonia musical do cosmo já é mencionada, por exemplo, no Timeu de Platão. Aristóteles criticou essas idéias, mas a concepção de uma harmonia universal no mundo físico perdurou por séculos nas visões cosmológicas e foi forte inspiradora para que Kepler chegasse a suas leis sobre o movimento dos planetas.

Além das relações gerais já apontadas entre música, física e matemática, alguns outros aspectos emergem nas suas relações com a ciência: a construção de instrumentos musicais, que guarda ligação direta com o conhecimento físico e tecnológico da matéria e da acústica; as relações profundas entre o tempo, um conceito central da ciência moderna, e a música, seus ritmos e freqüências; o comportamento sonoro, que inspirou modelos para a descrição da luz e que possibilitou posteriormente avanços importantes nos meios de comunicação; as mudanças profundas que a ciência e a tecnologia possibilitaram na reprodução em massa das obras de arte, aqui incluída a música; as conexões culturais mais amplas, subjacentes tanto à música como à ciência, duas componentes da atividade criativa humana, individual ou coletiva.

Do lado da história da arte e da história da ciência é importante destacar que, enquanto ocorria o processo que se denominou de revolução científica nos séculos XVI-XVII, surgia também uma profunda transformação na música, originada da transformação da prática artística. Como destacam Claude Palisca (1992) e Stillman Drake 
(1992), houve profundas conexões entre física e música naquele período em que emergia uma visão nova sobre a natureza e o homem.

Nosso objetivo neste artigo é muito mais restrito do que a análise das implicações gerais da relação entre ciência e música. Ele explora, de forma preliminar, um aspecto dessa relação complexa entre ciência e música: como, nas letras de canções da música popular brasileira, surgem e se expressam temas e visões sobre a ciência, a tecnologia e seus impactos na vida moderna. Examinamos letras de diversas canções sem nos preocupar com os outros elementos do discurso musical. Isso é evidentemente uma limitação forte, já que a música guarda uma integralidade entre a harmonia, o ritmo e as palavras. A aliança texto-música é matéria das mais antigas e sensíveis no campo da arte. Por isso, analisar somente os aspectos informativos e poéticos das letras musicais significa uma atitude redutora e um risco latente. Por exemplo, a análise das harmonias e ritmos, que sequer é tentada aqui, proporcionaria outras oportunidades para estudo da conexão música-ciência (Wisnik, 1999). Apesar dessa limitação, acreditamos que estudos como o nosso podem ajudar a investigar como temas de ciência e tecnologia estão presentes no imaginário de compositores.

Como lembra também Maria Izilda de Matos (2006), a produção musical pode ser vista como um corpo documental, uma fonte particularmente instigante para a historiografia, já que por muito tempo embalou boêmios, artistas populares e sambistas, entre outros. Essa autora destacou que a música é pouco explorada pela análise histórica e como instrumento com potencial didático. A análise das letras musicais pode ser um interessante momento para um exercício interdisciplinar, ainda mais que a música carrega elementos motivadores com potencial para despertar o interesse por determinado tema ou acontecimento, particularmente entre os jovens.

\section{Uma classificação preliminar}

Apresentaremos, no que se segue, trechos de letras de músicas provenientes do acervo da música popular brasileira, desde quando elas começaram a ser gravadas, no início do século passado. Consideraremos letras musicais que se referem de alguma forma a temas, conceitos, visões ou atitudes diante da ciência, da tecnologia e de seus impactos sobre os indivíduos e sobre a sociedade. No sentido de facilitar a análise, agrupamos tentativamente as letras examinadas de acordo com as seguintes categorias:

1. tratam de cientistas ou inventores brasileiros importantes, como Cesar Lattes ou Santos Dumont;

2. exploram ou têm como mote conceitos ou teorias científicas, como aquelas que se referem ao quantum de energia, ao DNA, aos fractais e aos conceitos fundamentais de tempo e espaço; 
3. mencionam e/ou se referem a conceitos e teorias científicas de forma secundária ou incidental, como várias músicas populares que usam como metáforas conceitos ou termos científicos de seu tempo - vacina, micróbio, penicilina etc. - para aplicá-los em diversos contextos e situações da vida social ou sentimental;

4. referem-se a eventos científicos ou tecnológicos marcantes, como a passagem do cometa Halley, a explosão da bomba atômica ou a chegada do homem à Lua;

5. abordam impactos diversos na vida social e individual decorrentes de avanços tecnológicos, como a vacinação obrigatória ou a introdução de aparatos tecnológicos diversos - a televisão, o computador, a Internet etc.;

6. criticam ou ironizam conseqüências dos usos da ciência e da tecnologia, como aquelas referentes à influência da tecnologia sobre o meio ambiente ou ao impacto nefasto da bomba atômica;

7. acompanham enredos carnavalescos que abordam temas de ciência e tecnologia, como o samba-enredo da escola de samba Unidos da Tijuca em 2004.

8. são exercícios de ficção científica.

Essa classificação é evidentemente superficial e é necessário aprimorá-la. Note-se que as fronteiras entre as categorias aqui apresentadas não são muito precisas; várias letras musicais mencionadas a seguir poderiam se enquadrar em mais de uma delas. Apesar disso, essa listagem pode ser útil como uma primeira tentativa classificatória ou pelo menos como um artifício didático para o acompanhamento deste texto.

As letras de música selecionadas a seguir são apenas alguns exemplos possíveis; muitas outras escolhas poderiam ter sido feitas. Nosso objetivo é destacar que uma análise da música popular, uma expressão artística tão forte no Brasil, pode conduzir a interessantes questionamentos sobre a relação entre ciência e cultura no país.

\section{Cientistas ou inventores brasileiros importantes}

Um samba emblemático foi "Ciência e Arte", de Cartola e Carlos Cachaça, composto em 1948 para a Mangueira. Destaca a obra do artista Pedro Américo e do físico Cesar Lattes, que, na época, ganhou as páginas de jornais e revistas por causa de sua participação decisiva na descoberta do méson pi:

Tu és meu Brasil em toda partel Quer na ciência ou na artel Portentoso e altaneiro/ Os homens que escreveram tua histórial Conquistaram tuas glórias/ Epopéias triunfais/ Quero neste pobre enredo/ Reviver glorificando os homens teus/ Levá-los ao Panteon dos grandes imortais/ Pois merecem 
muito mais/ Não querendo levá-los ao cume da altural Cientistas tu tens e tens cultura/ E neste rude poema destes pobres vates/ Há sábios como Pedro Américo e Cesar Lattes.

Nessa mesma linha, temos a marcha de Eduardo das Neves, "A Conquista do Ar", composta para homenagear Santos Dumont. Ela alcançou grande sucesso na época e recebeu várias gravações posteriores. Sua letra é típica do ufanismo que galvanizou o país em torno dos feitos do inventor:

A Europa curvou-se ante o Brasil/ E clamou "parabéns" em meio tom.l Brilhou lá no céu mais uma estrela:/ Apareceu Santos Dumont ...

A conquista do ar que aspiraval A velha Europa, poderosa e viril,/ Quem ganhou foi o Brasil!

Por isso, o Brasil, tão majestoso,/ Do século tem a glória principal:/ Gerou no seu seio o grande heróil Que hoje tem um renome universal.

Assinalou para sempre o século vintel O herói que assombrou o mundo inteiro:/ Mais alto que as nuvens. Quase Deus,/ Santos Dumont - um brasileiro.

Muitas outras composições - hinos, marchas e sambas - foram dedicadas posteriormente a esse personagem heróico. No acervo musical da Biblioteca Nacional, pode-se encontrar pelos menos uma dúzia delas. Mencionemos duas: uma é a marcha "Santos Dumont", de 1956, composição de Ataulpho Alves e Aldo Cabral. Outra homenagem, mais recente, é o samba-enredo de 2006 da escola de samba Unidos do Peruche, de São Paulo, que tem o título "Santos Dumont... Brasil e França navegando pelos ares".

Um conjunto musical que abordou a atividade de um cientista foi o Grupo Rumo. Em sua longa "A incrível história do dr. Augusto Ruschi, o naturalista e os sapos venenosos", escrita por Paulo Tatit (Álbum "Quero passear", 1988) e destinada a crianças e adolescentes, destacou-se a atividade preservacionista de Ruschi. Na sua segunda parte, descreve-se o envenenamento do cientista por sapos venenosos e envereda-se por uma senda de valorização de conhecimentos tradicionais indígenas, que teriam proporcionado sua cura:

Na América do Sul tem um país chamado Brasil onde acontecem coisas incríveis, e nós vamos contar como é que o naturalista Augusto Ruschi se tratou da doença terrível que ele pegou dos sapos venenosos.

Ele era naturalista porque gostava da natureza, estudava a natureza, entendia os bichos, as matas, as formigas, os passarinhos... e defendia a natureza! Não deixava ninguém derrubar árvores, queimar florestas, poluir rios, matar e arrancar a pele dos animais, não deixava ...

Dr. Augusto Ruschi, onaturalista, envenenado! Ai, ai, ai. Tentou os hospitais, as farmácias e drogarias, consultou médicos, falou com cientistas, especialistas, tomou remédio, fez dieta, fez de tudo, mas nada, nada, nada adiantava. 
A Conquista.do Ar !

Cantico a arrodado aeronauta
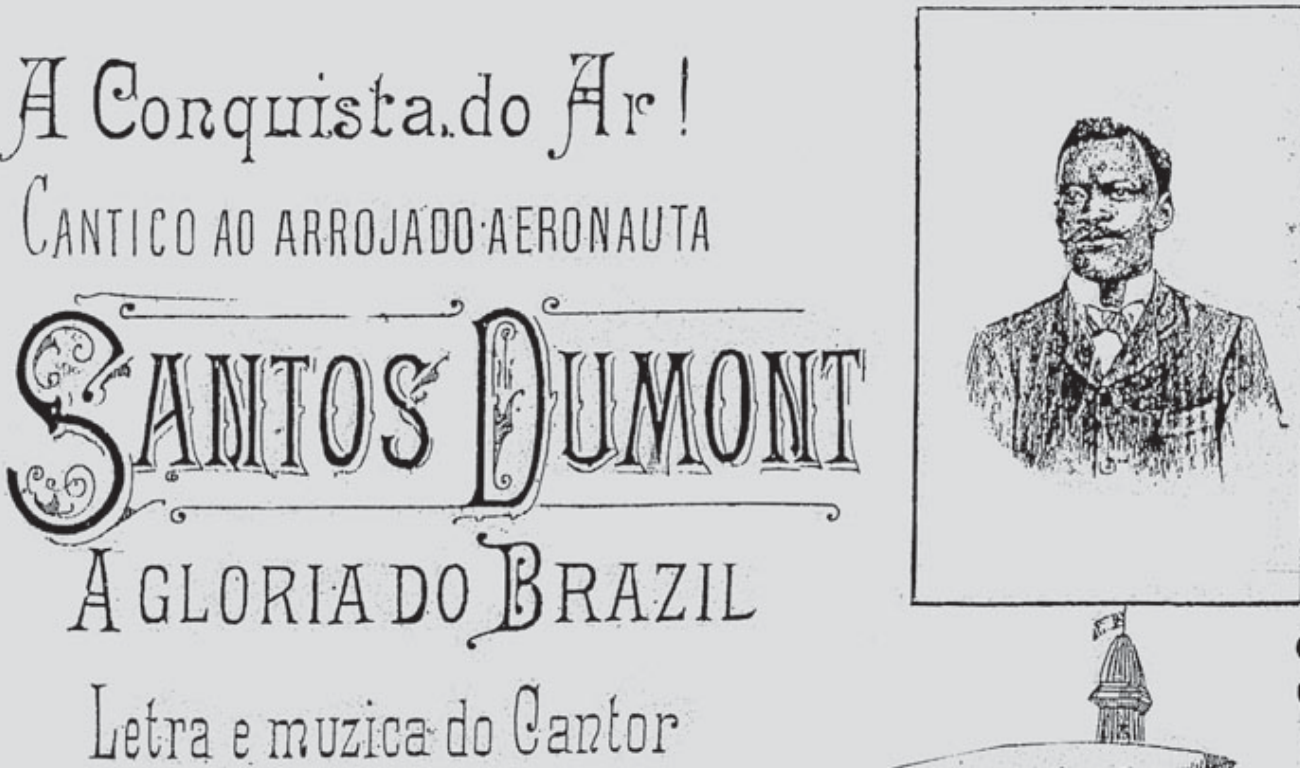

Letra e muzica do Cantor
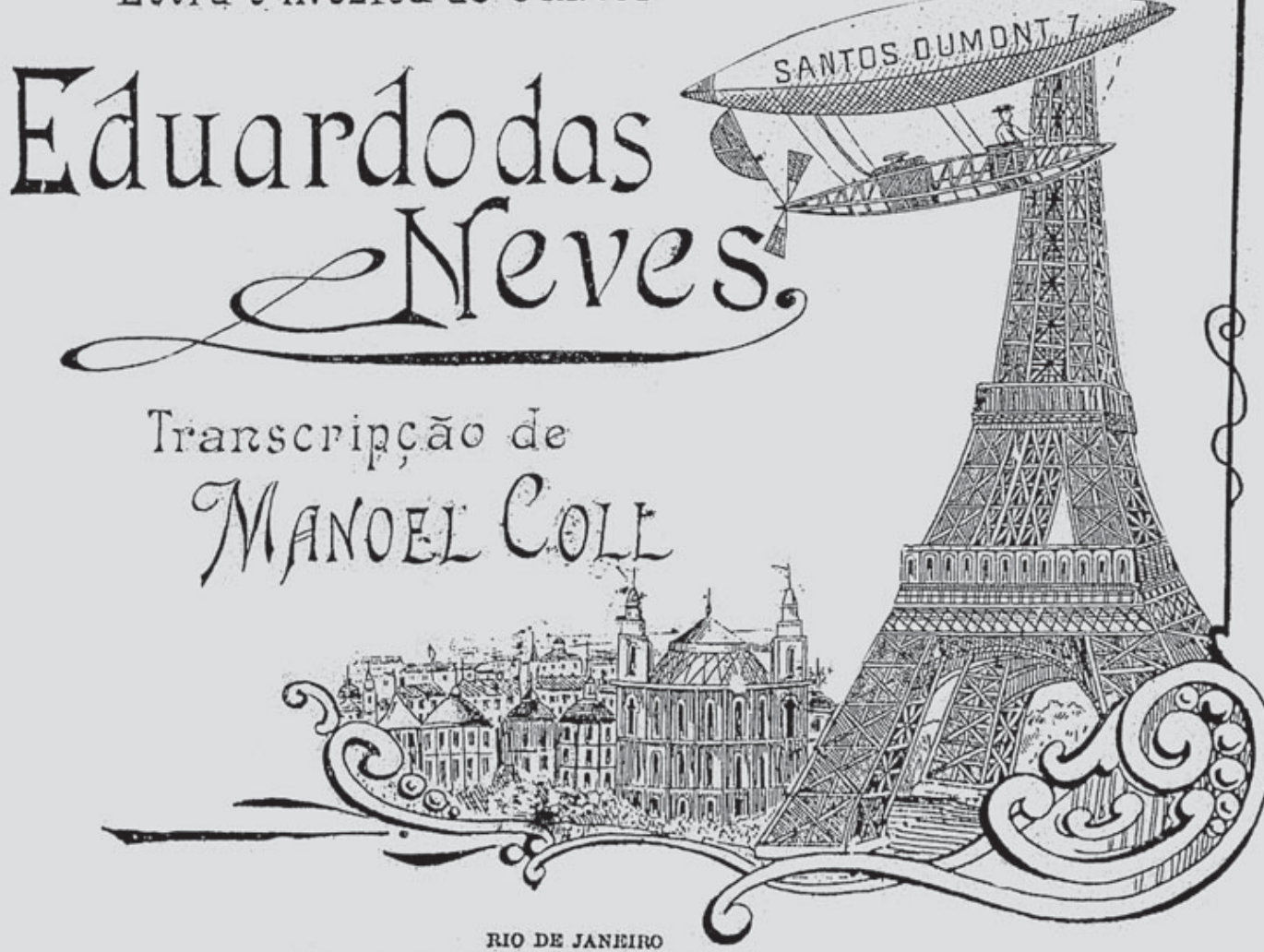

Luvraria do Povo - OUARESMA \& c. - Untrtritixt

Cópia cedida pela Biblioteca Nacional. 
E veio o cacique Raoni. E veio o pajé Sapaim ... Fumaram cigarros, deram banho de ervas, esfregaram as mãos, fizeram massagem... retiraram o veneno... curaram!

\section{Conceitos e teorias científicas}

Augusto dos Anjos já entronizava na poesia, com extrema habilidade, termos científicos e discussões de seu tempo - evolução e comportamento do cérebro, por exemplo. Na música de Gilberto Gil, "Quanta" (1995), ganhou espaço um conceito fundamental e complexo da física moderna: o quantum, introduzido por Planck como um artifício matemático no início do século $X X$, posteriormente estendido e tomado mais a sério por Einstein:

Quanta do latim/ Plural de quantum/ Quando quase não hál Quantidade que se medir/ Qualidade que se expressar

Fragmento infinitésimo/ Quase que apenas mental/ Quantum granulado no mel/ Quantum ondulado do sal/ Mel de urânio, sal de rádio/ Qualquer coisa quase ideal

Cântico dos cânticos/ Quântico dos quânticos/ ...

A beleza da matemática e da física, em particular dos fractais, atraiu César Nascimento e Alê Muniz ("Fractal", 1995). Eles dedicaram sua composição "à bravura e criatividade dos cientistas da América Latina":

Fractal pode ter belezal Fractal, apesar da certezal Fractal, ô, ô, revela beleza/ Dando se tira que em todo aço,/ Até no mais puro traço,/ Existe um momento tal,/ Existe um momento-flor/ Que poderá vir a ser fractal/ Traço um traço ao lado do traço/ Na diagonal da diagonal/ Fractal/ Uma fractal pode ter belezal Apesar da certezal Uma fractal pode ter.

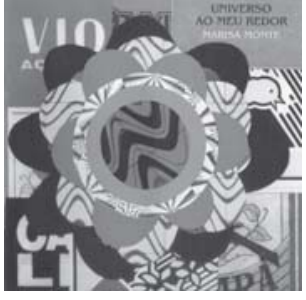

Reprodução de capa do cd Universo ao meu redor, cedida pela EMI.
Já Marisa Monte procura ciência nas coisas e lança mão de átomos em "AAlma e a Matéria", composição em parceria com Carlinhos Brown e Arnaldo Antunes:

Procuro nas coisas vagas ciêncial Eu movo dezenas de músculos para sorrirl Nos poros a contrair, nas pétalas do jasmim/ ...

Procuro na paisagem cadêncial Os átomos coreografam a grama do chão/ Na pele braile pra ler na superfície de mim/ Milímetros de prazer, quilômetros de paixão/ ...

Em “Átimo de pó", de Gilberto Gil e Carlos Rennó (1995), brincouse com o som e a rima de palavras relacionadas à ciência:

Entre a célula e o céu/ O DNA e Deus/ O quark e a Via-Lácteal A bactéria e a galáxia

Entre agora e o eon/O ín e Órion/ A lua e o magnéton/ Entre a estrela e o elétron/ Entre o glóbulo e o globo blue 


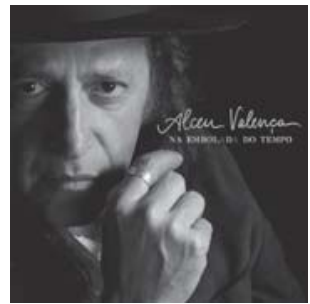

Reprodução de capa do cd Embolada do Tempo cedida por Indie Records Ltda.

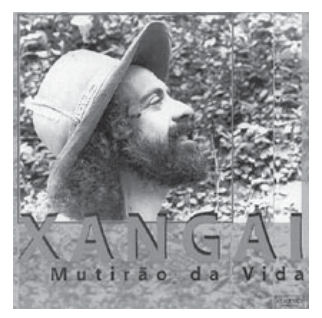

Reprodução de capa do cd Mutirão da vida cedida por Kuarup Discos.
Eu, um cosmos em mim só/ Um átimo de pól Assim: do yang ao yin Eu e o nada, nada não/ O vasto, vasto vão/ Do espaço até o spin/ ...

Na literatura poética universal, o tempo é um dos temas mais recorrentes, pela vinculação óbvia com a vida e a morte (Moreira, 2002). Na música, o tema também surge freqüentemente. Uma busca no site Rádio Terra, que reúne muitas composições, identifica 235 canções sob a palavra-chave 'tempo'. ${ }^{1}$ Mencionemos apenas duas. Caetano Veloso dedicou ao tema a sua bela "Oração ao Tempo" do disco "Outras palavras" (1981):

... Compositor de destinos/ Tambor de todos os ritmos/ Tempo, tempo, tempo, tempo/ Entro num acordo contigo/ Tempo, tempo, tempo, tempo

Por seres tão inventivo/ E pareceres contínuo/ Tempo, tempo, tempo, tempo/ um dos deuses mais lindos/ Tempo, tempo, tempo, tempo/ ...

Já Alceu Valença criou a "Embolada do Tempo" (incluído em CD de mesmo nome, 2005):

O tempo em sil Não tem fim/ Não tem começo/ Mesmo pensado ao avesso/ Não se pode mensurarl ...

Buraco negro/ A existência do nadal Noves fora, nada, nadal Por isso nos causa medo

Tempo é segredo/ Senhor de rugas e marcas/ E das horas abstratas/ Quando paro pra pensar/...

Você quer parar o tempo/ E o tempo não tem parada.

Uma canção na qual o espaço sideral surge como inspiração inicial e que se volta para a descrição da natureza e suas maravilhas, exemplificada aqui pelo trecho relativo ao poraquê, foi composta por Ivanildo Vilanova e Xangai ("Natureza", LP "Mutirão da vida", 1984): ${ }^{2}$

É o céu uma abóbada aureoladal Rodeada de gases venenosos/ Radiantes planetas luminosos/ Gravidade na cósmica camadal Galáxia também hidrogenadal Como é lindo o espaço azul-turquesal E o sol fulgurante tocha acesal Flamejando sem pausa e sem escalal Quem de nós pensaria apagá-lal Só o santo doutor da naturezal ...

O poraquê ou peixe-elétrico é um tipo genuíno/ Habitante dos rios e águas pretas/ Com ele possui certas plaquetas/ Que o dotam de um mecanismo fino/ Com tal cartilagem esse ladino/ Faz contato com muita ligeirezal Quem tocá-lo padece de surpresal Descarga mortífera absolutal Sua autovoltagem eletrocutal Com os fios da santa natureza ...

\footnotetext{
${ }^{1}$ Disponível no site da Rádio Terra (radio.terra.com.br/), acessado em 24.05.2006.

2 A 'natureza' também é tema recorrente na música, com 28 canções sob essa palavrachave em busca na Rádio Terra, com músicos variados, desde Chico César a Jamelão. O livro de Gloria Pondé, Rosa Riche e Vera Sobral (1992) traz também uma coletânea interessante de poesias e músicas sobre o tema da natureza.
} 
Termos e conceitos da biologia foram explorados no humor do grupo Casseta \& Planeta em "Mitocôndria" (1994): ${ }^{3}$

Todos vieram de lá. Ah! (bis)/ Mitocôndria, aparelho de Golgi/ Ribossomae membrana celular./ Todos vieram de lá ô, ô, do DNA, á,á(bis)/ Passando por microvilosidades e anticorpos, / As impurezas do organismo/Vão sendo absorvidas, absorvidas, absorvidas/ Purinas, pirinas e pirimidinas, / Fosfatos, glicídios e as vitaminas, / Combatendo as "toquicinas"/ Ribonucléico, desoxirribonucléico! (bis)/ Aêa, oi! A êa, oi! A êa, oi! tugurugudu!

Algumas letras abordam temas mais gerais da ciência, como "A Ciência em si", de Gilberto Gil e Arnaldo Antunes (1995). Ela integra o repertório do disco "Quanta", de 1997, que tem a ciência e a tecnologia como fonte de inspiração em várias das canções:

Se toda coincidêncial Tende a que se entendal E toda lendal Quer chegar aquil A ciência não se aprendel A ciência apreendel A ciência em sil ...

Se toda estrela cadentel Cai pra fazer sentido/ E todo mito/ Quer ter carne aquil A ciência não se ensinal A ciência inseminal A ciência em sil ...

\section{Conceitos, teorias e termos da ciência mencionados secundariamente}

Os invisíveis micróbios constituíram um tema de inspiração para a verve de vários compositores, a exemplo do samba "Micróbio do samba" (1942), de Amado Régis, e da marcha "Micróbio da feiúra" (1944), de Albertino Miranda, Arlindo Matilde e Nelson Trigueiro. Os efeitos desses minúsculos seres são sentidos também em "Micróbio do frevo" (lançado em 1954), interpretado por Jackson do Pandeiro, composição de Genival Macedo:

Eu só queria que um dia, / O frevo chegasse a dominar, / Em todo Brasil, / O micróbio do frevo é de amargar,/ Quando entra no salão é que,/ O povo prefere pra dançar,/ E cai na dobradiça, não há quem faça parar.

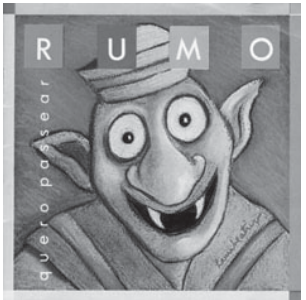

Reprodução de capa do cd Quero passear cedida por www.palavra cantada.com.br
O mundo microscópico também foi visitado pelo Grupo Rumo. O álbum "Quero Passear" (1988) traz "Micróbio, o dançarino infeliz", de Pedro Mourão, que usa uma estratégia comum no diálogo com crianças de personalizar os bichos:

Quantos bichos será que a terra tem? I - Milhões, milhões muito mais de cem.

Eu sei que tem bicho de todo tamanho/ E de tudo que é jeito/ Tem uns que são muito terríveis/ Tem outros que são imprevisíveis/ Mas aqueles totalmente invisíveis / Eu nunca vil ou melhor, eu nunca tinha visto/ porque um dia antes de dormir eu ouvi um ruído/ de bicho pequeno, miúdo, desses que a gente nem vê./ ...

\footnotetext{
${ }^{3}$ Há uma versão de "Mitocôndria" cantada pelo Coral da Fiocruz, que tem se destacado por seu trabalho com músicas envolvendo temas de saúde e ciência, sob a regência de Paulo Malaguti (Pauleira), tendo gravado um CD com as principais canções.
} 
Ele era um bicho esquisito/ Pequeno e miúdo e tão feio que só podia ser um desses micóbrios/ Micóbrio? / (Vai ver que é parente de cocodrilo.)

Produtos científicos ou tecnológicos que têm um impacto importante na sociedade, a exemplo da penicilina, são tomados como mote artístico, como pode ser visto na "Marcha da Penicilina", gravada em 1954 por Linda Batista. Note que ela não crê que a ciência médica resolverá todos os problemas 'doloridos' do ser humano:

Ai, Penicilina cura até defunto,/ Petróleo bruto faz nascer cabelo, / Mas ainda está pra nascer o doutor,/ Que cure a dor de cotovelo.

Vem desde os tempos de Adão,/ Essa dorzinha infernal,/ Foi comer a maçã,/ Logo que mordeu, / O cotovelo doeu...

Caetano Veloso em sua canção "Livro" falou da radiação do corpo negro e da expansão do universo:

Tropeçavas nos astros desastradal Quase não tínhamos livros em casa

E a cidade não tinha livrarial Mas os livros que em nossa vida entraram/ São como a radiação de um corpo negro/ Apontando pra a expansão do Universo/ Porque a frase, o conceito, o enredo, o versol (E, sem dúvida, sobretudo o verso)/ É o que pode lançar mundos no mundo.

Antonio Carlos Jobim e Marino Pinto (1958) exploraram de forma humorística uma "Aula de Matemática" para fazer uma declaração de amor:

Pra que dividir sem raciocinar/Na vida é sempre bom multiplicar/ E por A mais B/ Eu quero demonstrar/ Que gosto imensamente de você

Por uma fração infinitesimal,/ Você criou um caso de cálculo integral/ E para resolver este problemal Eu tenho um teorema banal

Quando dois meios se encontram desaparece a fração/ E se achamos a unidadel Está resolvida a questão

Prá finalizar, vamos recordar/ Que menos por menos dá mais amor/ Se vão as paralelas/ Ao infinito se encontrar/ Por que demoram tanto os corações a se integrar?/ Se infinitamente, incomensuravelmente, I Eu estou perdidamente apaixonado por você.

No início dos anos 1930, Noel compôs com Orestes Barbosa "Positivismo", na qual usa a lei de Augusto Comte para admoestar uma querida orgulhosa que o amor vem por princípio e o progresso por fim. Não descura de uma referência jocosa à situação econômica da época e aos juros exorbitantes:

... Vai orgulhosa querida/ Mas aceita esta lição:/ No câmbio incerto da vidal A libra sempre é o coração/ O amor vem por princípio/ A ordem por basel $O$ progresso é que deve vir por fim/ Desprezaste esta lei de Augusto Comtel E foste viver feliz longe de mim/ Vai coração que não vibral Com teu juro exorbitantel Transformar mais esta libral Em dívida flutuante. 


\section{Celebração de eventos científicos ou tecnológicos marcantes}

Eventos como a passagem de cometa Halley, a explosão da bomba atômica ou a chegada do homem à Lua atraíram a atenção de poetas, artistas e compositores. Para o caso da bomba, exemplos serão mencionados mais à frente. Quanto à passagem do Halley, destaquemos que ela foi motivo do interesse de compositores populares já na sua passagem de $1910{ }^{4}$ quando a letra da polca humorística "No Bico da Chaleira", de Juca Storoni (João José da Costa Jr.), sucesso do carnaval de 1909, foi adaptada com duplo sentido:

Lalá me deixa espiá nessa lunetal Eu sou do grupo que gosta do cometal Cometa do Halley, cometa do ar, / Levanta a cauda que eu quero espiar.

Em 1961, “A Lua é dos namorados", de Armando Cavalcânti, Klécius Caldas e Braguinha, referia-se à chegada próxima do homem à Lua e fazia a apologia do romantismo pretensamente ameaçado:

Todos eles estão errados/ A Lua é dos namorados/ Lua, ó Lual Querem te passar para trás/ Lua, ó Lual Querem te roubar a paz.

Lua que no céu flutual Lua que nos dáluar/ Lua, ó Lual Não deixa ninguém te pisar.

\section{Impactos diversos de avanços científicos e tecnológicos}

O surgimento das novas tecnologias de comunicação tem grande impacto na sociedade e considerável repercussão no universo musical. Desenvolvido no final do século XIX, o telefone começou a tornar-se mais popular depois de 1900. Ele vai surgir de forma incidental em um dos primeiros sambas brasileiros gravados, "Pelo telefone", de Donga e Mauro de Almeida, em 1916:

O Chefe da Folia/ Pelo telefone manda me avisar/ Que com alegria/ Não se questione para se brincar/ Ai, ai, ai/ É deixar mágoas pra trás, ó rapaz/ $\mathrm{Ai}$, ai, ai/ Fica triste se és capaz e verás/...

Em 1967, foi a vez de Chico Buarque tecer sua ironia poética e suas considerações sociológicas sobre o impacto da televisão na vida das pessoas:

O homem da rual Fica só por teimosia/ Não encontra companhia/ Mas pra casa não vai não/ Em casa a rodal Já mudou, que a moda mudal A roda é triste, a roda é mudal Em volta lá da televisãol ...

\footnotetext{
${ }^{4}$ Naquele ano, outras grandes sociedades (que antecederam as escolas de samba) incluíram também o tema do cometa em seus desfiles.
} 
Os namorados/ Já dispensam seu namoro/ Quem quer riso, quem quer choro/ Não faz mais esforço não/ E a própria vidal Ainda vai sentar sentida/ Vendo a vida mais vividal Que vem lá da televisão/ O homem da rual Por ser nego conformado/ Deixa a Lua ali de lado/ E vai ligar os seus botões/ No céu a Lual Encabulada e já minguando/ Numa nuvem se ocultando/ Vai de volta pros sertões.

Raul Seixas e Marcelo Nova se inspiraram em um novo equipamento para, sarcásticos, rirem da modernidade em "Você roubou meu videocassete" (1989):

Você roubou meu vídeo cassetel Pensando que eu fosse o controle remotol Pra frente e pra trás só na sual Cabeçal E antes que eu me esqueça "honey darling"/ É melhor desligar ...

Você é tão possessiva/ Guardou minha imagem na sua televisão/ Vocêé tão abusival Me prende e não muda pra outral Estação ...

Na década de 1990, Gilberto Gil incluiu "Pela Internet" no já mencionado álbum "Quanta" e, com ela, explorou o 'infomar', seus termos técnicos e a globalização emergente, fazendo referência ao mencionado "Pelo Telefone":

Criar meu web sitel Fazer minha home-page/ Com quantos gigabytes/ Se faz uma jangadal Um barco que veleje

Que veleje nesse infomar/ Que aproveite a vazante da infomarél Que leve um oriki do meu velho orixál Ao porto de um disquete de um micro em Taipél ...

Eu quero entrar na redel Promover um debatel Juntar via Internet/ Um grupo de tietes de Connecticut

De Connecticut acessar/ O chefe da Macmilícia de Milão/ Um hacker mafioso acaba de soltar/ Um vírus pra atacar programas no Japão

Eu quero entrar na rede pra contactar/ Os lares do Nepal, os bares do Gabão/ Que o chefe da polícia carioca avisa pelo celular/ Que lá na praça Onze tem um videopôquer para se jogar...

Ainda na linha das novas tecnologias, destaca-se "Cérebro Eletrônico", também de Gil (1969), gravado às pressas pouco antes de partir para o seu exílio londrino. O termo 'cérebro eletrônico', em voga em determinado período, foi hoje quase completamente substituído por 'computador':

O cérebro eletrônico faz tudo/ Faz quase tudo/ Faz quase tudo/ Mas ele é mudo

O cérebro eletrônico comandal Manda e desmandal Eleé quem manda/ Mas ele não andal ...

Eu penso e posso/ Eu posso decidir/ Se vivo ou morro por quêl Porque sou vivo/ Vivo pra cachorro e sei/ Que cérebro eletrônico nenhum me dá socorro/ No meu caminho inevitável para a mortel Porque sou vivo/ Sou muito vivo esei 
Que a morte é nosso impulso primitivo e seil Que cérebro eletrônico nenhum me dá socorro/Com seus botões de ferro e seus/ Olhos de vidro.

Vem de longe a presença na música popular de letras que retratam impactos que a ciência e a tecnologia ocasionam na sociedade. Destacamos a marcha "Vacina obrigatória", de autoria desconhecida, gravada em $1904^{5}$ e relacionada com a Revolta da Vacina, que ocorreu naquele ano contra a vacinação compulsória liderada por Oswaldo Cruz:

Anda o povo acelerado com horror à palmatórial Por causa dessa lambança da vacina obrigatória./ Os panatas da sabença estão teimando dessa vezl Em meter o ferro a pulso,/ Bem no braço do freguês.

E os doutores da higiene vão deitando logo a mão,/ Sem saberem se o sujeito/ Quer levar o ferro ou não./ Seja moço ou seja velho/ Ou mulatinha que tem visgo,/ Homem sério, tudo, tudo/ Leva ferro que é servido.

... Mas a lei manda que o povo e o coitado do freguês/ Vá gemendo na vacina ou então vá pro xadrez./ ...

Eu não vou neste arrastão sem fazer o meu barulho./ Os doutores da ciêncial Terão mesmo que ir no embrulho./ Não embarco na canoa, que a vacina me persegue./ Vão meter ferro no boil Ou no diabo que os carregue.

Também em 1904, as campanhas sanitaristas inspiraram Casemiro Rocha e Claudino Costa a comporem "Rato, rato", sucesso no carnaval. Em seu afã de controlar as doenças que assolavam a cidade, especialmente a peste bubônica, Osvaldo Cruz determinou uma desratização da cidade. Nessa campanha começou-se a comprar ratos, iniciativa também explorada pelos compositores, que carregam também nos preconceitos:

... Audacioso e malfazejo gabiru./ Rato, rato, rato / Eu hei de ver ainda o teu dia final/ A ratoeira te persiga e consiga, / Satisfazer meu ideal./ Quem te inventou? / Foi o diabo, não foi outro, podes crer/ Quem te gerou? / Foi uma sogra pouco antes de morrer!/ Quem te criou?/ Foi a vingança, penso eu/ Rato, rato, rato, rato / Emissário do judeu/ Quando a ratoeira te pegar, I Monstro covarde, não me venhas/ A gritar, por favor./ Rato velho, descarado, roedor/ Rato velho, como tu faz horror!/ Vou provar-te que sou mau / Meu tostão é garantido/ Não te solto nem a pau.

Décadas depois, seria a vez de as técnicas de inseminação artificial povoarem o imaginário dos artistas. É o caso da marcha "Bebê de Proveta", escrita por Braguinha. A música, surgida no carnaval de 1979, explorava o controverso anúncio do nascimento em julho do ano anterior de Louise Brown, o primeiro bebê de proveta:

5 Também gravada pelo Coral da Fiocruz. 
Bebê de proveta, / Bebê de mutreta, / O seu inventor, / Que cara careta.

Porque não sacou,/ Da sua veneta, / Que a gente prefere,/ Bebê de chupeta.

Romeu, Romeu,/ O que há com a sua Julieta?/ Trocou você, por um tubo de proveta.

\section{Crítica e ironias aos usos da ciência e da tecnologia}

Como os usos e abusos da ciência e da tecnologia ameaçam a humanidade? A bomba atômica não passou despercebida, pela força agressiva com a qual literalmente implodiu a sociedade. Jorge Mautner e Nelson Jacobina introduzem esse perigo no cotidiano, em "Cinco bombas atômicas", de 1985:

Cinco bombas atômicas/ Em cima do meu cérebro/ Quando eu era pequeno/ Saudades eletrônicas/ Cinco bombas atômicas/...

A poesia de Vinícius de Moraes foi combinada com a melodia de Gerson Conrad para fazer grande sucesso com "Rosa de Hiroshima", na gravação do grupo Secos \& Molhados, de 1973:

Pensem nas crianças/ Mudas telepáticas/ Pensem nas meninas/ Cegas inexatas/ Pensem nas mulheres/ Rotas alteradas/ Pensem nas feridas/ Como rosas cálidas/ Mas, oh, não se esqueçam/ Da rosa da rosa/ Da rosa de Hiroshima/ A rosa hereditária/ A rosa radioativa/ Estúpida e inválida/ A rosa com cirrose/ A anti-rosa atômica/ Sem cor sem perfume/ Sem rosa sem nada.

$\mathrm{Na}$ "Saga da Amazônia" (LP Sagas Brasileiras, 1982), Vital Farias canta o destino trágico da floresta amazônica:

Era uma vez na Amazônia a mais bonita florestal mata verde, céu azul, al mais imensa florestal no fundo d'água as Iaras, caboclo lendas e mágoas/e os rios puxando as águas/ ...

No lugar que havia mata, hoje há perseguição/ grileiro mata posseiro só prá the roubar seu chão/ castanheiro, seringueiro já viraram até peão/ afora os que já morreram como ave-de-arribação/ ...

Aqui termina essa história para gente de valor/ prá gente que tem memória, muita crença, muito amor/prá defender o que ainda resta, sem rodeio, sem arestal era uma vez uma floresta na Linha do Equador...

Na linha da crítica aos danos ao meio ambiente, Aguinaldo Batista e Luiz Gonzaga apresentam uma visão pessimista, em "Xote Ecológico" (1989) e homenageiam o grande seringueiro e ambientalista brasileiro Chico Mendes:

Não posso respirar, não posso mais nadar/ A terra tá morrendo, não dá mais pra plantar/Se planta não nasce se nasce não dál Até pinga da boa é difícil de encontrar/ Cadê a flor que estava ali?/ Poluição comeu./ E o peixe que é do mar?/ Poluição comeu/ E o verde onde que está?/ Poluição comeu/ Nem o Chico Mendes sobreviveu. 


\section{Ciência nos sambas-enredo}

Uma outra dimensão importante nas músicas são os sambasenredo do carnaval. Desde os primeiros desfiles, no começo do século XX, temas ou referências a eventos ou resultados da ciência estiveram presentes de tempos em tempos. ${ }^{6}$ Citaremos aqui apenas um exemplo, já que uma análise mais aprofundada da ciência no carnaval brasileiro - que ainda está por ser feita - exigiria considerações sobre as representações da ciência no desfile por inteiro, em especial nas alegorias, alas e fantasias. "O sonho da criação e a criação do sonho: a arte da ciência no tempo do impossível" foi o enredo da Unidos da Tijuca, que ficou em segundo lugar no carnaval do Rio de Janeiro de 2004:

Nessa máquina do tempo, eu vou/Vou viajar... (com a Tijuca te levar)/ À era do Renascimento/ De sonhos e criação/ Desejos, transformação/ Acreditar, desafiar/Superar os limites do homem/ Brincar de Deus, criar a vidal Querer voar e flutuar

Na arte da ciêncial A busca continual Na luta incessante pra vencer o mall E no vaivém dessa histórial O velho sonho de ser imortal ...

\section{Letras que são exercícios de ficção científica}

As músicas que têm em suas letras elementos de ficção científica são inúmeras, em particular após a década de 1970. “Dois mil e um" é uma composição de Rita Lee e Tom Zé, cantada pelos Mutantes (LP “Mutantes", 1969):

Astronauta libertado/ Minha vida me ultrapassal Em qualquer rota que eu faça/ Dei um grito no escuro/Sou parceiro do futuro/ Na reluzente galáxia

Eu quase posso falar/ A minha vida é que grital Emprenha se reproduz/ Na velocidade da luz/ A cor do sol me compõel O mar azul me dissolvel A equação me propõel Computador me resolvel ...

"Ficção Científica", da lavra de Renato Russo, promove misturas e associações livres, mas não descura da crítica social e registra a realidade da ficção:

Hoje à noite/ Flash Gordon/ Vai tentar ser/ Barbarella/ Para ver sel Aprisional Albert Einstein.

Quem criou/ O Elixir da/ Longa vidal Ainda vive/ Tenta criar/ Uma nova bomba H./ ...

Criptonital No meu sanguel Clorofórmio/ No banheiro/ E a dançal É a mesma, / Não é ficção!

\footnotetext{
${ }^{6}$ Um artigo, escrito por Ronaldo Mourão, fez recentemente um primeiro levantamento desse tema fascinante.
} 
Revolução!!!/ Em selvas tropicais/ Raio laser/ Mata índios/ Descoberta!/ O novo mundo envelheceu ...

Muita fome/ Nas estrelas;/ Muita fome/ Nas estrelas;/ Muita fome/ Nas estrelas;/ E aqui também!

O rebelde Raul Seixas explorou o limite da velocidade da luz em "A Geração da luz", composição em parceria com Kika Seixas (1984), em que deixou seu recado para nosso futuro. A ciência não acabou:

Eu já ultrapassei a barreira do som/ Fiz o que pude às vezes fora do tom/Mas a semente que eu ajudei a plantar já nasceul Eu voul Eu vou m'embora apostando em vocês/ Meu testamento deixou minha lucidez/ Vocês vão ver um mundo bem melhor que o meu/ Quando algum profeta vier lhe contar/ Que o nosso sol tá prestes a se apagar/ Mesmo que pareça que não há mais lugar/Vocês ainda têm/Vocês ainda têm/A velocidade da luz pra alcançar/...

\section{Considerações finais}

As canções foram sempre um referencial importante sobre a cultura de sua época e as visões, representações e atitudes do homem diante do mundo, da vida e da sociedade. A ciência e as visões sobre ela e seus impactos permeiam a cultura popular e encontram expressão através da pena de poetas e compositores. Às vezes, temas de ciência ou conceitos dela emanados assumem papel proeminente nas letras; em outras ocasiões a referência à ciência e aos avanços tecnológicos é apenas secundária ou incidental dentro da temática do poema musicado. Buscamos aqui identificar alguns exemplos em que temas de ciência e tecnologia povoaram o imaginário de compositores da música popular brasileira. A possibilidade de esses materiais adquirirem uso didático ou voltado para a divulgação científica pode ser inferida, mas não foi, aqui, ponto de interesse maior. Longe de apresentar um trabalho abrangente sobre o tema, nosso objetivo foi ilustrar, por meio da música, que a ciência faz parte do tecido cultural da sociedade brasileira, servindo de inspiração para muitos artistas, poetas e compositores. Temos ainda a pretensão de estimular a memória e a reflexão do leitor curioso, que certamente encontrará diversos exemplos similares dentro da música brasileira.

Terminemos esta nossa viagem musical com Raul Seixas, buscando nele elementos para a tese perene de que a música tem uma relação profunda com o universo e sua descrição pelos humanos. Na composição com Oscar Rasmussen "O Segredo do Universo" (1979), ele associou o mambo ao segredo do universo. Mesmo se discutível a tese, ela nos convida a refletir, ou quem sabe a dançar no ritmo musical do universo:

Dentro do mambo e da consciêncial Está o segredo do universo/ Dentro do mambo e da consciêncial Está o segredo do universo ... 


\section{REFERÊNCIAS BIBLIOGRÁFICAS}

Drake, Stillman

1992

Matos, Maria Izilda

Santos

2006

Moreira, Ildeu de

Castro

2002

Palisca, Claude

1992

Pondé, Gloria; Riche,

Rosa; Sobral, Vera

1992

Wisnik, José Miguel 1999
Musics and Philosophy in Early Modern Science. In: Coelho, Victor (ed.)

Music and science in the age of Galileo. Dordrecht: Kluwer Academic

Publishers. p. 3-16.

'Saudosa Maloca' vai à Escola.

Nossa história, v. 3, n. 32, p. 80-2.

Poesia na sala de aula.

Física na escola, v. 3, n. 1, p. 17-23.

Was Galileo's Father an Experimental Scientist? In: Coelho, Victor (ed.) Music and science in the age of Galileo. Dordrecht: Kluwer Academic Publishers. p. 143-52.

Brasil em cantos e versos: natureza.

São Paulo: Melhoramentos.

O som e o sentido.

2. ed. São Paulo: Companhia das Letras.

Recebido para publicação em junho de 2006.

Aprovado para publicação em julho de 2006. 


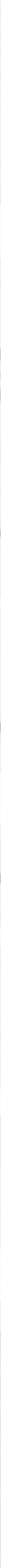

